1. A Tríplice Aliança;

2. Pequena empresa e internacionalização na produção;

3. Uma coalizão nacionalista no centro? 4. Repercussões nacionalistas; 5. Economia transnacional e politica nacional.

Peter Evans**

* Tradução do original em inglês por Paulo Lollato e revisão técnica por Regina Laura de Souza Pinto.

** Professor do Departamento de Sociologia da Brown University, USA.
(...) Existe uma convicção cega e ingênua, no estrangeiro, no sentido de que, no fundo, os interesses das massas coincidem com os interesses pecuniários dos homens de negócio que vivem na esfera do mesmo conjunto de normas governamentais.

Thorstein Veblen. A Teoria da empresa comercial 1904.

Tendo chegado ao Brasil independentemente de convite e sendo alojado pelos brasileiros de propósito em um hotel, em vez de em uma residência oficial, seria difícil a Jimmy Carter deixar de perceber que, na primavera de 1978, as relaçð̃es Brasil-EUA estavam seguindo uma nova direção. Para alguns observadores as mudanças eram confusas. Quando o Brasil renunciou à ajuda militar dos EUA, os colunistas conservadores Evans e Novak começaram a falar, de modo um tanto histérico, de como "o Brasil poderia passar a liderar um bloco de centro-direta antiamericano no Hemisfério Ocidental"'.

Econômica e politicamente havia novos elementos nas relaçð̄es Brasil-EUA: enquanto a Comissão de Comércio Internacional dos EUA criava dificuldades para os exportadores brasileiros de produtos manufaturados, a Interbrás, a maior das trading companies estatais, procurava obter mercados na União Soviética e na Europa Oriental; e enquanto dirigentes da Associação dos Trabalhadores da Indústria Automobilística (UAW) começavam a se preocupar com o número de motores Pinto que chegavam do Brasil para Detroit, os industriais brasileiros, por sua vez, reclamavam de que a Comissão de Comércio Internacional dos EUA estava sendo protecionista em relação à indústria americana. Ao mesmo tempo em que a Interbrás negociava a montagem de refrigeradores e condicionadores de ar na Nigéria e a construção de hotéis no Iraque, protestava-se no Congresso americano contra o aumento da exportação de aço brasileiro para os EUA.

Para as multinacionais americanas que operam no Brasil, a situação passava a apresentar aspectos inquietantes. Havia "uma certa perplexidade em virtude da crescente tensão restritiva nas atitudes governamentais com relação à sua presença na economia". ${ }^{1}$ A inquietação foi acentuada pelo surgimento de uma minuta de proposta de um grupo brasileiro produtor de maquinarias cuja intenção era restringir a ação das multinacionais; proposta na qual, de acordo com Business Latin America, "a linguagem e as acusações repetiam os ataques mais veementes dos criticos da esquerda ao capital estrangeiro"'.2 Para as multinacionais, as preocupações potenciais com o nacionalismo eram combinadas com receios de que, se os desentendimentos políticos entre os governos brasileiro e americano não fossem resolvidos, "o comércio e o investimento americano na região pudessem ser postos de lado em favor de novos investidores europeus e japoneses" ${ }^{3}$

Haveria, na realidade, uma diferença nas relaçðes Brasil-EUA? Afinal de contas, as multinacionais americanas continuam a manter uma posição de comando na economia brasileira. $O$ comércio entre os dois paises ainda consiste, principalmente, no intercâmbio de matérias-primas do Brasil de produtos manufaturados dos EUA. A estrutura básica de dependência permanece, quer Jimmy Carter fique num hotel ou não. 
Uma análise das relaçð̃es Brasil-EUA ainda deve começar pelos modelos de estrutura de classe e de relaçð̃es comerciais desenvolvidos pelos teóricos do imperialismo e da dependência. Ao mesmo tempo, seria um erro descartar as controvérsias atuais como meramente efêmeras e transitórias, pois estas indicam alterações a longo prazo que afetam as estruturas de classes dentro - bem como as relações de classe entre tanto na periferia como no centro.

Um dos pontos-chave para início da análise do crescimento econômico na periferia sempre foi o papel do capital estrangeiro em relação ao desenvolvimento nacional. O imperialismo preocupa até mesmo os latinoamericanos que são a favor do desenvolvimento capitalista, porque ele supõe uma cisão entre os interesses do capital e o desenvolvimento das forças produtivas locais. Na medida em que o capital tem suas origens no estrangeiro, ele pode preferir negligenciar os problemas da acumulação local, levando o excedente e utilizando-o para favorecer a acumulação em outros lugares. A desconfiança do capital estrangeiro caminha paralelamente ao mito da "burguesia nacional", a classe empresarial local com um projeto de desenvolvimento. Presume-se que uma burguesia nacional latino-americana teria um engajamento inevitável com o desenvolvimento das forças produtivas locais, embora não necessariamente para com a distribuição dos frutos do aumento da produtividade. Mas a emergência de uma burguesia nacional é vista como uma possibilidade problemática, ou até mesmo inatingível.

Nos paises do centro, é tomada como certa a existência de uma burguesia nacional. A lealdade nacional do capital é questionada somente por cínicos, subversivos e algum populista ocasional. Subsidiar a acumulação do capital no estrangeiro é justificado enquanto os donos do capital estão domiciliados no país. E assumido que as aventuras internacionais do grande capital contribuem para a acumulação local. Serão abertos mercados, o suprimento de matérias-primas será assegurado, os lucros, remetidos de volta - e o país central, e também sua classe operária, serão beneficiados.

Na periferia, o grande capital e o capital estatal são, em parte, antagônicos na medida em que o grande capital é estrangeiro. A ausência de uma burguesia nacional coloca um pesado fardo empresarial sobre o Estado. Os nacionalistas são cautelosos a respeito da abertura para a economia internacional. $\mathrm{O}$ comércio externo, como o capital estrangeiro, é uma faca de dois gumes, às vezes facilitando o desenvolvimento local, mas facilitando talvez somente a dependência e subvertendo o desenvolvimento local. Para o centro, a economia internacional é uma arena para o engrandecimento nacional e uma via para a resolução do conflito de classes interno. John Robson e Cecil Rhodes concordavam em que o imperialismo permitia continuar a acumulação sem distribuição.

O fato principal para a evolução das relaçōes entre o Brasil e os EUA é que, embora apresentando muitos aspectos de dependência, o Brasil está começando a assumir características "semelhantes às dos países centrais" . O Estado brasileiro considera a sério a possibilidade de o capital vir a ser subordinado às necessida- des da acumulação local, independentemente de suas origens estrangeiras; assim sendo, o Brasil começou a colocar seus produtos com mais agressividade no mercado internacional. Ao mesmo tempo, os Estados Unidos, sofrendo no balanço de pagamentos déficits tão crônicos como aqueles que atormentam o Brasil, voltaram a considerar sobre se a abertura para a economia internacional ainda seria de seu interesse. Simultaneamente, começaram a surgir dúvidas sobre se o fato de os donos do capital serem cidadãos americanos é uma garantia suficiente de que a expansão do capital servirá aos interesses nacionais.

Essas tendências são as únicas reconhecidas e ainda não se apresentam de forma bastante forte para transformar as estruturas fundamentais de imperialismo e dependência. As relações entre a General Motors e o Estado brasileiro serão sempre diferentes das relaçőes entre a GM e o aparato político dos EUA. Não obstante, há uma tendência inegável no sentido de um crescente afastamento das multinacionais da política de seus países de origem e um estreitamento de laços entre elas e certos Estados semiperiféricos como o Brasil. De maneira similar, há paralelos marcantes entre as situaçōes enfrentadas pelo capital nacional brasileiro e pelo pequeno capital orientado para a economia interna nos Estados Unidos. Ambos se consìderam dependentes e, ao mesmo tempo, prejudicados pelos recursos sobre o comando do capital internacional.

Explorar essas tendências curiosas requer a cobertura de áreas discrepantes e aparentemente desconexas. A natureza da atual "tríplice aliança" que une as multinacionais, o Estado e a elite do capital nacional no Brasil será o nosso ponto de partida. As contradições desta tríplice aliança e o papel essencial das exportações para sustentar $o$ modelo brasileiro também devem ser examinados. Um estudo do impacto das mudanças da economia internacional sobre o crescimento econômico e a mão-de-obra dos EUA dá seqüência às considerações sobre os problemas econômicos brasileiros. Finalmente, um exame das variedades de reações nacionalistas ${ }^{4}$ ao capital internacional, tanto no Brasil quanto nos Estados Unidos, fornecerá a dinâmica política que complementa a análise econômica.

\section{A TRÍPLICE ALIANÇA}

Com a promulgação da idéia de "desenvolvimento associado dependente" por F. H. Cardoso, os estudiosos do imperialismo começaram a examinar de modo mais detalhado a hipótese de que o capital internacional estivesse invariavelmente em oposição à industrialização, em todos os lugares da periferia. ${ }^{5}$ Analisando as estatísticas sobre o investimento estrangeiro em áreas 'menos desenvolvidas desde 1945, nota-se que houve um aumento dramático no investimento estrangeiro direto na área de manufaturas. Este investimento não atingiu grande parte do Terceiro Mundo, mas em alguns dos maiores e mais bem dotados paises menos desenvolvidos tornou-se parte de uma arrancada importante para a industrialização.

Paises como o Brasil e o México mudaram o suficiente para serem considerados semiperiféricos ao 
invés de partes da periferia verdadeira. ${ }^{6}$ Esses paises não se envolveram apenas na substituição de importação "fácil", mas também na produção de bens básicos e intermediários. A imagem clássica do desenvolvimento do Terceiro Mundo, como uma luta entre o interesse pela industrialização de uma nascente burguesia nacional e o capital estrangeiro, interessado em manter o país em seu lugar tradicional na divisão internacional de trabalho, começa a perder cada vez mais seu sentido. A acumulação parece, de fato, estar baseada numa tríplice aliança entre as multinacionais, um segmento dos maiores detentores de capital local e o Estado empresarial.

Considerar a estrutura da elite de países como o Brasil como sendo caracterizada pela tríplice aliança não significa rejeitar a possibilidade de conflitos entre as elites. ${ }^{7}$ A noção de tríplice aliança acompanha a idéia de Sunkel de "desintegração nacional e integração transnacional" na medida em que sugere uma ruptura importante entre os maiores grupos detentores de capital e o resto da burguesia brasileira.$^{8}$ Esses grupos, que Cardoso, Falette e outros denominaram de "burguesia internacionalizada", podem participar do processo de acumulação acionado pela tríplice aliança. ${ }^{9} \mathrm{~A}$ participação do resto da burguesia local é parcial, problemática e altamente dependente da sua capacidade de manter o acesso político efetivo aos níveis mais altos do aparato estatal.

Além dos conflitos criados pela marginalização de parte da burguesia local, certas contradiçōes persistenı entre os interesses do capital internacional e as necessidades locais de acumulação. Haverá sempre uma diferença entre os objetivos do nacionalista, que enfatiza o completo desenvolvimento da divisão do trabalho interno, e as estratégias requeridas pelo capital internacional. A estimativa das multinacionais sobre a. gama de atividades e indústrias que se deve implantar no Brasil será sempre menor que a estimativa dos nacionalistas. A multinacional não vê razão em correr riscos para prover o Brasil com particularidades que possam beneficiar o processo global de acumulação, mas que não tragam benefício para a empresa. A multinacional tem opções e deve exercê-las de uma maneira que preserve sua flexibilidade e liberdade de ação. $O$ nacionalista e a multinacional devem sempre operar com alguma tensão entre si, mesmo que ambos não estejam preocupados com questões de bem-estar social ou distribuição.

O Estado brasileiro tem de ser nacionalista no sentido de continuar a pressionar as multinacionais para dar prioridade à acumulação local, pois de outra forma suas próprias bases econômicas estariam minadas. Este tipo de nacionalismo, guiado pelas necessidades objetivas da acumulação local, poderia ser chamado de "nacionalismo dos planejadores", ou, no Brasil, de "nacionalismo do CDI"' (derivado do Conselho de Desenvolvimento Industrial, que decide sobre que projetos industriais devem gozar de incentivos fiscais). $O$ nacionalismo do CDI é complementado pelo da burguesia local - quer dos elementos excluidos da triplice aliança, quer dos que estão tentando melhorar sua posição dentro dela. O nacionalismo é uma arma ideológica útil para proteger sua parte na arena indus- trial. Pode ser chamado de "nacionalismo da ABDIB" (derivado de Associação Brasileira pelo Desenvolvimento da Indústria de Base, que contém alguns dos nacionalistas mais fervorosos da burguesia local).

A maior mudança estrutural em termos de propriedade industrial durante o período do "milagre" (aproximadamente 1968-1974) foi, como Newfarmer e Mueller sutilmente demonstraram, não um declínio na participação brasileira, mas sim um declínio na participação privada brasileira. ${ }^{10}$ Do ponto de vista do nacionalismo do CDI isto não representa um desastre, mas pode mesmo ser visto como uma melhora, dependendo da avaliação que se tenha sobre a eficiência das corporaçōes estatais. Também não representa um desastre do ponto de vista dos grandes grupos privados brasileiros, que fazem parte da "burguesia internacionalizada" de Cardoso e Faletto ou do "grupo transnacional" de Sunkel. Como Cardoso e outros já notaram, os ativos das maiores firmas brasileiras aumentaram durante o milagre tão ou mais rapidamente que os ativos dos grupos estrangeiros. " Um problema político foi criado, todavia, e sua magnitude seria substancialmente ampliada se um aumento na democratização alargasse o segmento da burguesia local que tem acesso ao aparato estatal.

Os dois tipos de nacionalismo são, na prática, difíceis de-separar. Juntos, eles resultam uma tensão persistente entre a elite brasileira e as multinacionais. Não obstante, o aspecto dominante desta relação é de colaboração em torno do interesse comum na acumulação local do capital. Para as multinacionais americanas, o desenvolvimento dependente, sob a égide da tríplice aliança, tem sido bastante lucrativo no Brasil. A maioria das estimativas das taxas de lucro para as filiais brasileiras é pelo menos $50 \%$ maior do que as taxas de lucro das grandes corporações dentro dos Estados Unidos. ${ }^{12}$ No fim da década de 60 e início da década de 70, o Brasil forneceu às multinacionais um amplo campo para expansão, num período em que as economias desenvolvidas não estavam crescendo rapidamente. Incentivos fiscais e um crescimento significativo, tanto no mercado de bens duráveis quanto no de bens de produção, assim como controles rígidos sobre a mão-de-obra e aparato estatal relativamente previsível e receptivo tornaram o Brasil um pais atraente.

No fim de 1976, o valor dos investimentos americanos na indústria, no Brasil, aproximava-se de quatro bilhơes de dólares. Tais investimentos só eram suplantados pelos realizados no Canadá, Inglaterra, França e Alemanha Ocidental. A tríplice aliança cresceu em tais proporções que nem o Estado brasileiro nem as multinacionais podem pensar em dissolvê-la. Por isso, as dimensठ̃es do envolvimento das multinacionais no Brasil ressaltam as contradiçðes contidas na triplice aliança e prenunciam que suas tentativas de negociar com essas contradições terão repercussōes em seu comportamento em outras partes do mundo.

As lutas dentro da tríplice aliança não assumirão a forma de conflito interno com o objetivo de arrasar os outros participantes; tomarão a forma de barganha e negociação entre parceiros cujos interesses se entrecruzam e que reconhecem o mérito um do outro. Um 
grande número de barganhas pode ser agrupado sob o título geral de controle. Ambos os nacionalismos, o do CDI e o da ABDIB, gostariam de limitar o poder e a área de manobra das multinacionais forçando-as a dividir o controle em seus empreendimentos - quer submetendo-as a maior regulamentação que permita aos sócios locais uma participação igualitária e conseqüentes prerrogativas decisórias, quer exigindo maior transferência de tecnologia.

Por seu lado, as multinacionais não podem permitir que a localização de seus estabelecimentos no Brasil levem ao que se pode denominar de "efeito de Moran" - diminuição do poder de barganha proporcional à segurança dos ativos investidos no país-hóspede. ${ }^{13}$ Elas devem lutar para preservar o relativo monopóiio da tecnologia que possuem. Inversamente, na medida em que a posição das multinacionais torna-se cada vez mais importante para os setores dinâmicos da economia brasileira, revela-se essencial um maior controle local sobre as multinacionais para que o Estado brasileiro possa dirigir o processo de acumulação. Estão na agenda assuntos tais como cortes nas prerrogativas legais das multinacionais forçando-as a efetuarem investimentos conjuntos e, talvez ainda mais importante, restriçðes às suas vantagens tecnológicas através da obrigação explícița de compartilhar tecriologia. Dentro da estrutura geral de colaborações e de interesse comum, a luta pelo controle continuará intensa.

O melhor exemplo recente de luta por obtenção de controle é a controvérsia de 1977 sobre a indústria de minicomputadores. O Brasil estabeleceu a participação nacional igualitária e a tecnologia aberta, isto é, "a transferência efetiva de tecnologia para mãos brasileiras, sem cláusulas restritivas", como o critério básico de aprovação de incentivos para a instalação local de fábrica de computadores. ${ }^{14} \mathrm{~A}$ IBM, que não tem investimentos conjuntos nem mesmo nos EUA, estava disposta a construir seu modelo 32 no Brasil, se lhe fosse permitido operar como única detentora do capital. Outras grandes indústrias de computadores, tais como a Data General, participavam das reações adversas da IBM às condições impostas pelos brasileiros.

Se as multinacionais tivessem sido os únicos setores envolvidos, a capacidade de barganha do Brasil teria sido mínima, mas, infelizmente para elas, este não era o caso. A Digibrás, companhia estatal holding na indústria de computadores, estabeleceu uma subsidiária, a Cobra, também estatal, com participação de capital privado nacional. A Cobra, por sua vez, adquiriu know-how e peças da companhia americana Sycor. Desde que se evidenciou que a Cobra poderia produzir minicomputadores no Brasil, a Capre, agência brasileira encarregada de regulamentar a indústria de computadores, ficou em condições de interromper a importação de minicomputadores e, assim, afastar qualquer multinacional que não aceitasse seus termos. Para aumentar a pressão, a Capre estabeleceu que somente duas firmas, além da Cobra, seriam autorizadas a montar indústrias de minicomputadores. A multinacional que demorasse a ceder seria, portanto, definitivamente afastada.

Um dos aspectos mais interessantes da estratégia nacionalista neste caso foi a utilização pelo Brasil de uma firma americana "orientada para o mercado interno" como instrumento para aumentar seu poder de barganha contra as multinacionais. A Sycor é uma firma muito pequena que nunca poderia considerar a sério um confronto com a IBM no mercado americano. Com poucos anos de existência em 1976, e menos de 2.000 empregados, teria sido um competidor considerado inviável pelo mercado brasileiro se agisse por conta própria. Como empresa minúscula, teria muito menos a perder ao dividir sua tecnologia com o Brasil, e essa tecnologia era o ingrediente vital necessário à Cobra para colocar-se numa posição de barganha bastante vantajosa diante das indústrias multinacionais de computadores.

Um tipo bem diferente de solução para a questão do controle é ilustrado pelas manobras da Dow Chemical em meados da década de 70. A Dow entrou no Brasil relativamente tarde, com grandes projetos, e supreendentemente conseguiu estabelecer-se numa base de capital exclusivo. ${ }^{15}$ Embora não quisesse aceitar participantes locais no seu capital, estava decidida a fazer importantes investimentos no desenvolvimento da tecnologia local, e reservou mais de cinco milhões de dólares para a instalação de um centro de pesquisa e desenvolvimento, seu quarto maior centro de pesquisa do mundo. ${ }^{16}$ Com este gesto no sentido de reduzir a dependência tecnológica do Brasil, a Dow reduziu também a possibilidade de que seu controle exclusivo sobre as próprias operações fosse ameaçado.

A adaptabilidade das multinacionais varia de companhia para companhia e a pressão do Governo brasileiro sobre elas irá variar de acordo com as flutuações do clima político local e o grau de importância de outros problemas econômicos. O primeiro entre esses outros problemas é o desequilíbrio da balança comercial brasileira.

Um dos pontos fracos mais óbvios do modelo brasileiro atual é a ênfase conferida às importações. Se for verdade, como a Comissão Econômica para a América Latina anunciou há alguns anos atrás, que "para $1 \%$ do crescimento do produto, o volume das importações deve aumentar em $2 \%$ ", ou o padrão de crescimento interno deve ser alterado, ou as exportaçðes devem continuar a crescer de maneira impressionante. ${ }^{17} \mathrm{O}$ aumento no preço do petróleo agravou o problema, mas as necessidades de importação de bens de capital e intermediários para as multinacionais são elementos fundamentais da importação intensiva no quadro do desenvolvimento brasileiro. Um estudo feito pelo Ministério do Planejamento mostrou que dois terços do déficit comercial brasileiro, excluido o petróleo, poderiam ser atribuídos às atividades de pouco mais de 100 multinacionais. ${ }^{18}$

Do ponto de vista das multinacionais, a natureza de sua expansão no Brasil, baseada na importação intensiva, não é nada desvantajosa. Cerca de $70 \%$ de toda a exportação de produtos manufaturados dos EUA para o Brasil era "relacionada com as multinacionais", de acordo com uma enquete da Comissão de Tarifas dos EUA. ${ }^{19}$

Embora a industrialização sob a forma de importação intensiva não seja desvantajosa para as multina- 
cionais, ela representa um problema crítico para o Brasil. Durante o milagre, desequilíbrios na balança comercial, juntamente com um saldo negativo de serviços, criaram um crescente déficit nas contas correntes, financiado por empréstimos externos até que o custo da dívida chegou a ser igual a $40 \%$ das exportações. Algo deveria ser feito e havia duas possibilidades. A primeira seria reduzir as importações, que consistiam basicamente em bens de capital e produtos intermediários.

A criação de uma indústria local de bens de capital foi tentada em certas áreas, assim como o aprofundamento do processo de industrialização, mas seu sucesso, pelo menos durante o início da década de 70 , foi limitado. ${ }^{20}$ A proporção de bens de capital adquiridos por meio da importação aumentou em vez de diminuir, entre 1967 e $1974 . .^{21}$ Além disso, a tentativa de criar uma indústria local de bens de capital levantou o problema da definição de "local" no sentido de "domiciliado no Brasil" ou de "propriedade brasileira".

A expansão da indústria local de bens de capital poderia ser tão lucrativa para as multinacionais como a substituição da importação de bens de consumo duráveis. Mas a clara preferência do Brasil por um setor de produção de bens de capital de propriedade nacional é um embaraço para as multinacionais, embora isto não tenha afetado seus empreendimentos. Na primavera de 1977, por exemplo, o Fundo Industrial para a Aquisição de Máquinas e Equipamentos - (o órgão de financiamento de equipamentos industriais do BNDE) fechou a lista de subsidiárias estrangeiras das quais as companhias brasileiras poderiam comprar equipamentos e obter apoio na forma de financiamento com baixas taxas de juros. Esta medida poderia dificultar extremamente aos fornecedores estrangeiros ainda não aprovados o suprimento de equipamentos para o lucrativo mercado das empresas estatais e teria cortado o acesso desses fornecedores ao mercado privado local. Felizmente para as multinacionais, um grupo de bancos alemães e japoneses reuniu-se e negociou um empréstimo ao BNDE, responsável pelo Finame; bancos ingleses e americanos foram chamados a participar e finalmente um fundo de 150 milhōes de dólares foi destinado ao Finame para o uso específico de empresas estrangeiras. ${ }^{22} \mathrm{O}$ objetivo havia sido atingido, pois enquanto fossem envolvidos apenas fundos brasileiros, a preferência seria dada à burguesia local.

Um outro exemplo marcante ocorreu quando o sistema estatal de ferrovias abriu concorrência para uma compra de 140 locomotivas. A General Electric, a única companhia que há anos produz locomotivas no Brasil, naturalmente esperava ganhar a concorrência. Mas a GE é uma companhia de capital integralmente estrangeiro e tinha sido acusada de participar de um cartel para "dizimar sistematicamente" os produtores locais de equipamentos elétricos. ${ }^{23}$ Ao invés da GE, a Equipamentos Villares, uma companhia que nunca construiu uma locomotiva, mas que era presidida por Carlos Villares, um dos mais ardorosos defensores do nacionalismo da ABDIB, ganhou a concorrência. ${ }^{2+}$

Do ponto de vista dos principais países, e em especial daqueles que, como os EUA, têm seus próprios probleınas de bảanço de pagamentos, uma das compensações para a transferência de crescentes quantidades de capacidade industrial para os países da semiperiferia tem sido o correspondente crescimento do mercado de maquinaria implantada. Um estudo patrocinado pelo Departamento de Comércio dos EUA no início dos anos 70 estimava, por exemplo, que as exportações de produtos têxteis brasileiros, no valor de 145 milhões de dólares, eram quase igualadas pelas importaçðes de mâquinas têxteis, que chegavam a 115 milhões de dólares. A conexão entre a expansão da indústria no Brasil e a expansão do mercado de exportaçð̃es foi tornada explícita, pois o relatório aconselhava os industriais americanos a considerar "as vantagens de montar operações subsidiárias no Brasil para fabricação completa ou parcial e, assim, propiciar uma plataforma para o aumento das importações". Igualmente, o Pólo Petroquímico do Nordeste, que foi planejado para fornecer substitutos nacionais para produtos intermediários importados, foi visto pelo Departamento de Comércio dos EUA como um mercado potencial para 250 milhões de dólares de equipamentos importados..$^{25} \mathrm{~A}$ expansão da indústria de bens de capital na semiperiferia removeria essa compensação. Um setor de bens de capital de propriedade local seria uma dupla perda.

A produção local de bens de capital é muito atrativa do ponto de vista nacionalista, e tanto os nacionalistas do CDI como os da ABDIB aplaudem a maior divisão de trabalho local e as oportunidades para o capital nacional que dai derivam. Mas ela constitui uma solução parcial e problemática para os problemas da balança de comércio: parcial, porque deixa inalterado o déficit criado pelas importações de bens intermediários; problemática, porque cria uma nova área de tensão entre as multinacionais e os nacionalistas da ABDIB. Escapar do déficit comercial pela expansão das exportaçðes é diferente. Multinacionais, capital nacional e Estado podem unir-se com facilidade em torno desta estratégia.

Para as multinacionais, exportar do Brasil oferece a oportunidade de substituir a produção americana de baixo lucro pela produção brasileira de lucro elevado. Suprir do Brasil e não dos Estados Unidos os mercados de outros paises do Terceiro Mundo dá às multinacionais a oportunidade de tirar proveito dos generosos incentivos que o Brasil oferece às exportações. Por exemplo, o Business International comentou que, para uma subsidiária da Tenneco que tentava resolver como supriria de tratores e equipamentos de construção o mercado da Nigéria, "ter o Brasil como base é boa perspectiva porque o Governo brasileiro, através da CACEX (semelhante ao Export-Import Bank dos EUA), oferece melhores termos de crédito do que os EUA". ${ }^{26}$ A revista Business Week mencionou o Brasil como sendo "um funil para as mercadorias destinadas à África negra". ${ }^{27}$ A Massey Ferguson descobriu que o Brasil também era um "funil útil para as mercadorias destinadas à Ásia", e que poderia vender 53 milhões de dólares para uma Turquia pobre de divisas sem correr nenhum risco cambial se fabricasse tratores no Brasil e os vendesse por intermédio da Interbrás. Antes, as vendas à Turquia tinham sido feitas através do Reino 
Unido, mas, como o vice-presidente da Massey Ferguson explicou, "estávamos encontrando problemas para obter créditos de exportação do Reino Unido e o Brasil estava ansioso por aumentar suas exportaçōes."

Para a burguesia local - mesmo para aqueles elementos que não podem propriamente ser chamados de membros da burguesia internacional - 0 aumento das exportaçð̃es de bens manufaturados ofereceu uma grande oportunidade. Indústrias como a têxtil e a de calçados, ainda consideradas tradicionais no fim dos anos 60 , eram, em meados de 70 , significativos contribuintes para as exportaçðes brasileiras; no curto período de três anos entre 1971 e 1973, as exportaçð̃es de têxteis em geral aumentaram cinco vezes e as exportaçðes de têxteis acabados aumentaram oito vezes. Os frutos dessa expansão beneficiaram em parte os membros da escala relativamente menor da burguesia local. Os bens que requerem para sua produção trabalho intensivo e tecnologia rotineira, com os quais o Brasil tem mais chance de ser internacionalmente competitivo, são o mesmo tipo de bens que as firmas de capital local estão aptas a produzir.

As companhias estatais não estão envolvidas de modo direto na fabricação desse tipo de bens que o Brasil exporta, mas podem envolver-se, na medida em que está ocorrendo uma integração vertical e elas começam a processar os produtos primários que estão exportando hoje como matérias-primas. Os passos para a integração vertical que já foram dados pela Companhia do Vale do Rio Doce são exemplos básicos. Além disso, a Interbrás, subsidiária trading da Petrobrás, está-se tornando um fator importante na comercialização de ampla variedade de exportações brasileiras. A expansão das exportaçð̃es, talvez mais importante do ponto de vista das companhias estatais, renova uma significativa barreira aos seus próprios planos de investimento ao aliviar a pressão para restringir importaçðes.

$O$ enfoque dado às exportaçð̃es alivia tensões sobre a expansão das multinacionais. $\mathrm{Na}$ medida em que a produção das multinacionais é claramente destinada às exportações, pode ser melhor justificada em termos de nacionalismo e é menos ameaçadora ao capital local. Enquanto as multinacionais puderem apresentar-se como máquinas para a expansão das exportaçð̃es, elas terão mais facilidade de acesso a novos setores e menos chances de serem desafiadas nas questðes de controle $e$ intercâmbio tecnológico. Por fim, é claro, a expansão das exportaçð̃es diminui a pressão sobre as multinacionais para reduzir suas importações de bens de capital e de produtos intermediários, da mesma forma que o faz para as empresas estatais.

A melhor ilustração de como a promoção de exportaçðes propicia uma solução mutuamente aceitável para os conflitos potenciais entre as multinacionais e o Governo brasileiro é fornecida pelo programa chamado Befiex, que alia um generoso conjunto de incentivos fiscais a um bom desempentio do balanço de pagamentos. No setor automobilístico, o Brasil conseguiu o comprometimento de todas as grandes indústrias para exportar um total de quase 6 bilhōes de dólares de sua produção num periodo de alguns anos."* Para as indústrias automobilisticas, esse com- prometimento é o mesmo que "receber o mapa da mina". Considerando os incentivos envolvidos, é certo que elas obterão maiores lucros em sua produção para exportação a partir do Brasil do que o conseguiriam de qualquer outro lugar. Elas também estarão numa posição bastante forte para exigir ainda maiores incentivos quando os compromissos iniciais se extinguirem em meados da década de 80 , pois nessa época o Brasil estará totalmente integrado nos seus programas de busca mundial de recursos. Para o Brasil, por sua vez, o programa Befiex representa uma contribuição substancial para a solução dos desequilíbrios comerciais. A indústria automobilística, que foi responsável em 1972-73 por um déficit na conta corrente do balanço de pagamentos da ordem de 180 milhões de dólares, estava a caminho de produzir um excedente quase tão grande em meados de $1977 . .^{29}$

Vista apenas em termos de dinâmica interna da aliança brasileira, a promoção da exportação gera lucros, acumulação local e harmonia. Infelizmente, obter a cooperação das multinacionais é apenas metade da questão para a elite brasileira, quando o objetivo é promoção das exportações; o mercado externo é a outra metade, $e$ isto significa enfrentar a política interna dos países principais.

$O$ primeiro fato evidente ao analisarmos a situação comercial do Brasil é que, com exceção do caso especial do petróleo, os problemas de sua balança comercial se originam das relaçðes comerciais que mantém com os países principais. Como mostra o quadro 1 , o Brasil teve déficits comerciais maciços no início dos anos 70 com os EUA, Japão e Alemanha Ocidental as economias "principais". As balanças comerciais muito favoráveis com seus vizinhos menos desenvolvidos e com os países socialistas são de magnitude insuficiente para contrabalançar seus déficits com os países principais. Mesmo depois de 1974, com a crise do petróleo, esses países ainda eram sua maior fonte de déficits. Os déficits comerciais com os países desenvolvidos eram quase o dobro do déficit produzido pelo comércio com o Oriente Médio.

Quando se observa a expansão das exportaçōes através do tempo, os paises principais aparecem como o maior problema do comércio brasileiro. Entre 1964 e 1974, as exportaçð̃es se expandiram de modo dramático com os países menos desenvolvidos e com o bloco socialista, embora a exportação aos países prirtcipais tivesse permanecido bem atrás do crescimento geral das exportações. Uma notável expansão em pequenos mercados não é o suficiente: para que a expansão das exportações tenha sucesso, essas exportaçồes devem penetrar cada vez mais nos grandes mercados mundiais.

O problema da penetração nos mercados dos paises industriais avançados é esclarecido pela análise de outra tendência mostrada nos quadros 2 e 3 - o papel crescente dos bens manufaturados entre as exportações do Brasil. Os produtos primários ainda são importantes, e em anos em que uma boa colheita coincide com tendências favoráveis do mercado, como em 1977 , a exportação de produtos primários pode mesmo crescer mais rápido que a exportação de manufaturados. Mas a tendência geral é clara: os produtos manu- 
faturados devem continuar participando com uma parcela cada vez maior das exportaçōes brasileiras se se quiser manter seu ritmo de expansão. $O$ Banco Mundial projetou um aumento na parcela das exporta- çס̃es dos bens manufaturados para $37 \%$ em 1985 e ressaltou que as "perspectivas de crescimento do Brasil dependem diretamente do crescimento da exportação de manufaturados". ${ }^{30}$

\section{Quadro 1}

Balança comercial do Brasil - 1972 e 1974, antes e depois da crise do petróleo (milhões de dólares norte-americanos)

\begin{tabular}{|c|c|c|c|c|}
\hline $\begin{array}{l}\text { Áreas de } \\
\text { comércio }\end{array}$ & Importaçð̄es & Exportaçōes & Diferença & $\begin{array}{l}\text { Diferença: } \\
\text { Percentagem } \\
\text { sobre as } \\
\text { importaçðes }\end{array}$ \\
\hline \multicolumn{5}{|l|}{1972} \\
\hline $\begin{array}{l}\text { Todos os países } \\
\text { desenvolvidos }\end{array}$ & 3.677 & 3.020 & -657 & $-18 \%$ \\
\hline EUA, Japão, Alemanha Ocidental & 2.355 & 1.447 & -908 & -39 \\
\hline Oriente Médio & 374 & 38 & -334 & -90 \\
\hline Bolívia, Uruguai, Paraguai & 29 & 89 & +60 & +206 \\
\hline Países socialistas & 91 & 288 & +197 & +217 \\
\hline Total & 4.775 & 3.991 & -784 & $-16 \%$ \\
\hline \multicolumn{5}{|l|}{1974} \\
\hline Todos os paises desenvolvidos & 9.576 & 5.618 & -3.958 & $-41 \%$ \\
\hline $\begin{array}{l}\text { EUA, Japão, Alemanha Ocidental } \\
\text { Oriente Médio }\end{array}$ & $\begin{array}{l}6.445 \\
2.404\end{array}$ & $\begin{array}{r}2.862 \\
431\end{array}$ & $\begin{array}{l}-3.583 \\
-1.973\end{array}$ & $\begin{array}{l}-56 \\
-82\end{array}$ \\
\hline Bolívia, Uruguai, Paraguai & 165 & 251 & +86 & +52 \\
\hline Paises socialistas & 189 & 415 & +226 & +120 \\
\hline Total & 14.162 & 7.951 & -6.211 & $-44 \%$ \\
\hline
\end{tabular}

Fonte: Naç̃es Unidas. Anuário de Estatísticas do Comércio Internacional. New York, 1976. v. 1: 1974 - quadro por pais.

Nota: As áreas são selecionadas, e, portanto, não se adicionam aos totais.

\section{Quadro 2}

Crescimento das exportaçð̃es brasileiras por tipo de mercadoria (miihões de dólares norte-americanos)

\begin{tabular}{|c|c|c|c|}
\hline $\begin{array}{l}\text { Tipo de } \\
\text { mercadoria }\end{array}$ & 1969 & 1974 & $\begin{array}{r}\text { Percentagem } \\
\text { do aumento }\end{array}$ \\
\hline Produtos primários & 2.066 & 5.804 & $181 \%$ \\
\hline Bens manufaturados & 245 & 2.147 & 776 \\
\hline Total & 2.311 & 7.951 & $244 \%$ \\
\hline $\begin{array}{l}\text { Manufaturados como percentagens } \\
\text { do total das exportaçōes }\end{array}$ & $11 \%$ & $27 \%$ & 一 \\
\hline
\end{tabular}

Fonte: IBGE. Anuário Estatistico 1972 p. 279-82; 1976 p. 245-47. Serra, José. Three mistaken theses on the connection between authoritarianism and economic development. In: Collier, David, ed. The New authoritarianism in Latin America. Princeton, New Jersey, 1978. quadro 10.

\section{Quadro 3}

Crescimento das exportaçōes brasileiras por destino

\begin{tabular}{l|r|r|r}
\hline Destino & 1969 & 1975 & $\begin{array}{c}\text { Percentagem } \\
\text { do aumento }\end{array}$ \\
\hline EUA & 609 & 1.337 & $120 \%$ \\
Europa Ocidental & 1.069 & 3.242 & 203 \\
Bolívia, Uruguai, Paraguai & 34 & 328 & 865 \\
África & 24 & 399 & 1.563 \\
Países socialistas & 129 & 829 & 543 \\
Total & 2.311 & 8.669 & $275 \%$ \\
\hline
\end{tabular}

Fonte: IBGE Anuário Estatístico 1972 p. 279-81; 1976 p. 245-47. Serra, José. op. cit. quadro 10. 
O cenário para a futura expansão das exportações do Brasil é claro. O grande déficit que tem caracterizado suas relações comerciais com os países principais deve ser superado pela colocação de uma proporção crescente de bens manufaturados nesses mercados. Este cenário vai diretamente ao encontro do que é chamado "o novo protecionismo"'. Business Latin America resumiu a situação do Brasil de forma suscinta: "Economicamente, a maior alteração pode ser vista na luta do Brasil para exportar: pela primeira vez, está começando a penetrar em áreas alheias. Quando suas exportações eram somente de produtos primários, 0 Brasil não interferia no caminho de ninguém. Mas agora, ao competir por mercados de produtos manufaturados tais como carros, equipamentos de construção de estradas, rádios, sapatos e tesouras, o Brasil está encontrando os mesmos problemas que afligem outras sociedades industriais. Estão sendo levantadas objeçōes aos incentivos para a exportação do Brasil, e medidas protecionistas estão sendo invocadas. Este tipo de resposta às suas exportaçoes constitui o período mais crítico das relaçðes Brasil-EUA". ${ }^{31}$

\section{PEQUENA EMPRESA E INTERNACIONALIZAÇÃO NA PRODUÇÃO}

No Brasil, a pequena empresa de capital nacional foi deixada para trás pela internacionalização da economia brasileira. Isso pode ser visto como um mal peculiar das burguesias periféricas, mas é, de fato, fenômeno mais geral. As pequenas companhias farmacêuticas no Brasil têm muito em comum com os pequenos fabricantes de calçados da Nova Inglaterra. Mesmo localizada no centro, a pequena empresa não está em posição de efetuar investimentos diretos e não está preparada para tirar vantagens das oportunidades de exportação. ${ }^{32}$ Ela está preparada, em geral, para fabricar os produtos de tecnologia rotineira que o Brasil está tentando exportar. $O$ efeito devastador que a expansão das exportações da semiperiferia pode ter sobre a pe- quena empresa nos paises mais importantes é ilustrado pela situação da indústria de calçados dos EUA.

Um sumário do rápido declínio da indústria de calçados americana diante da competição das importações por um período de 11 anos é fornecido no quadro 4 . Mais de 70 mil empregos desapareceram entre 1966 e 1976, junto com $30 \%$ da capacidade efetiva da indústria. Aqueles que permaneceram empregados também não se beneficiaram do aumento de rendimentos baseado em operaçôes mais mecanizadas ou na eliminação de fábricas ineficientes. Os ganhos médios dos que puderam manter os seus empregos na indústria permaneceram estagnados em termos reais e declinaram em relação aos ganhos de outras indústrias. $O$ valor adicionado por empregado na indústria de calçados declinou de $52 \%$ da média das indústrias em 1964 para $47 \%$ em 1974. Em resumo, a indústria de calçados nos EUA não estava se tornando mais moderna, nem uma indústria com menos trabalho-intensivo, mas estava simplesmente perdendo para a competição estrangeira.

A mudança estrutural mais importante da indústria durante o período 1966-1976 foi um aumento marcante no grau de concentração. No começo do período, 517 pequenas companhias partilhavam pouco mais de $1 / 4$ do mercado nacional, ao passo que 16 grandes companhias repartiam entre si pouco mais de $30 \%$ desse mesmo mercado. No fim do periodo, 21 grandes companhias eram responsáveis por metade da produção, enquanto 292 companhias pequenas tinham apenas $1 / 5$ do mercado. Trezentas companhias tinham desaparecido por completo.

A estrutura das importaçōes também se alterou durante o periodo. O Japão e a Inglaterra, que eram partes importantes da importação de calçados em 1966, tinham perdido essa importância em 1976. A contribuição da Itália e da Espanha permaneceu expressiva durante todo o período, mas Formosa, Coréia e Brasil, três paises que significaram menos de $1 \%$ do volume

\section{Quadro 4}

O declínio da indústria americana de calçados e o crescimento das importaçð̃es

\begin{tabular}{|c|c|c|c|}
\hline & 1966 & 1976 & $\begin{array}{r}1976 \text { como } \\
\text { percentagem } \\
\text { de } 1966\end{array}$ \\
\hline Total de empregados & 241.500 & 169.000 & $70 \%$ \\
\hline Número de empresas & 675 & 376 & 56 \\
\hline Capacidade efetiva ( 1.000 pares) & 782.952 & 568.404 & 73 \\
\hline $\begin{array}{l}\text { Levantamento da produção (1.000 } \\
\text { pares) }\end{array}$ & 641.696 & 413.087 & 69 \\
\hline Importaçðes (1.000 pares) & 96.135 & 369.814 & 384 \\
\hline $\begin{array}{l}\text { Valor das exportações (milhöes de } \\
\text { dólares) }\end{array}$ & $2.473,5$ & 3.482 & 141 \\
\hline $\begin{array}{l}\text { Valor das importaçð̃es (milhões de } \\
\text { dólares) }\end{array}$ & 158 & 1.448 & 916 \\
\hline Ganho médio semanal ${ }^{1}$ & $\$ 71,81$ & $\$ 70.22$ & 98 \\
\hline
\end{tabular}

Fonte: Associação Americana das Indústrias de Calçados. Footwear Manual 1977. quadros 10, 11, 37, 38; AFIA Statistical Reporter. Relatório Trimestral 4. trim. 1977.

1 A cifra para 1966 é a média aproximada dos lucros sémanais em dólares. A cifra para 1976 é a dos lucros aproximados deflacionados pela mudança do índice de preços para consumidores de 1966 a 1976. 
em dólares nas exportaçð̃es de calçados em 1966, contribuíram com mais de $40 \%$ no fim do período. Em resumo, os ganhos reais foram obtidos pela semiperiferia.

Para as centenas de pequenos empresários que foram afastados do negócio e para os 70 mil trabalhadores que perderam seus empregos, a mudança do investimento fabril para a semiperiferia foi um desastre. $\mathrm{Na}$ medida em que exemplos similares se acumulam, torna-se cada vez mais difícil para as multinacionais e seus defensores afirmar que investimentos no estrangeiro combinados com o livre comércio resultam numa política econômica ótima do ponto de vista dos "interesses nacionais". Como apontou Luciano Martins, a evolução da economia internacional durante as décadas de 60 e 70 "tornou bastante difícil para as corporações multinacionais apresentar seus interesses particulares como sendo o 'interesse geral' dos Estados Unidos". 33

Durante as últimas duas décadas, as multinacionais têm aumentado seus investimentos no estrangeiro numa proporção muito maior que seus investimentos nacionais. Esta tendência acelerou-se de modo particular durante os anos 70. Em 1960, o desempenho de capital estrangeiro das multinacionais americanas representava $11,5 \%$ do gasto nacional total nas indústrias manufatureiras; em 1974, os gastos estrangeiros constituíam $30,9 \%$ da despesa nacional. Esses gastos cresceram a uma taxa de $16,4 \%$ ao ano de 1960 a 1974 , enquanto o desembolso nacional cresceu apenas $8,5 \%$. No período de 1969 a 1974, a discrepância entre a expansão nacional e a estrangeira era ainda maior: os gastos de capital estrangeiro aumentaram $18,3 \%$ ao ano e os nacionais, somente 7,8\%. ${ }^{34}$ Ao mesmo tempo em que as fábricas estrangeiras estavam-se expandindo, a parcela mundial das exportações americanas de manufaturados declinava em cerca de $1 / 3.35$

Qual teria sido o resultado, se o Governo dos EUA tivesse tentado impedir a internacionalização da produção, proibindo o capital americano de ir para o estrangeiro? Deixando de lado a questão de como seria possível, tecnicamente, impedir tais fluxos de capital, a resposta seria que o capital (que neste caso quer dizer as multinacionais) estaria em pior situação, ao passo que o trabalhador americano provavelmente estaria em melhor condição. Usando as estimativas de Peggy Musgrave para os efeitos de renda agregada, verificamos que, sem investimento estrangeiro direto, o trabalho deveria ter um aumento, tanto no seu nível de renda absoluta quanto na sua parcela proporcional da renda. Se fosse possível analisar os lucros do pequeno capital de forma independente dos lucros do grande capital, é provável que os resultados para o pequeno capital fossem iguais aos do trabalho. Só é possível, porém analisar o lucro do trabalho, os lucros sobre o capital e o lucro nacional geral. As conclusōes de Musgrave são: "primeiro, que o investimento estrangeiro tem significantes efeitos distributivos, que atuam em detrimento do trabalhador", e segundo, que "a taxa liquida de lucro sobre invest imento estrangeiro com esta margem, e considerada sob o ponto de vista nacional, é negativa'".
A maior parte das discussões a respeito dos efeitos dos investimentos estrangeiros tem focalizado os resultados do emprego, mais que os da renda. Os estudos que encontram efeitos positivos no nível de emprego tendem a chegar a tais conclusões por admitir que os mercados estrangeiros estariam perdidos sem os investimentos diretos. Além disso, os empregos que poderiam estar sendo gerados pelo investimento nacional dos mesmos fundos são deixados fora da equação. ${ }^{37}$ Utilizando-se de hipóteses mais moderadas, Frank e Freeman, em um estudo patrocinado pelo Departamento de Estado dos EUA, concluíram que cerca de um milhão de empregos foram perdidos como resultado do investimento no estrangeiro, entre 1966 e 1973.38 Estudos como estes tornam a vida mais difícil para as multinacionais. Em 1950, quando $3 / 4$ da produção mundial de automóveis tinha origem nos EUA e quando este país exportava automóveis para o Brasil, a frase "O que é bom para a General Motors é bom para os EUA" era ainda plausível. Agora, que a produção de Detroit estagnou enquanto a GM e a Ford estão expandindo sua produção em outras partes do mundo, e, pior ainda, quando se observa motores do Brasil vindo para os carros de Detroit e rádios do Brasil indo para outros Ford, torna-se difícil ver a correspondência de interesses.

Não que as multinacionais tenham ficado sem argumento. O Prof. Stobaugh expôs o caso de modo sucinto ao subcomitê sobre as multinacionais, no Senado dos EUA:" (...) investimento americano, investimento estrangeiro direto são partes de um ciclo para se gerar novos produtos e novos conhecimentos nos EUA, e nós estamos exportando esses conhecimentos e esses produtos e estamos obtendo lucros monopolísticos gerados por essa atividade e por sua vez compramos produtos acabados [de tecnologia rotineira] com o dinheiro obtido dessas exportações de bens e serviços" ${ }^{39}$ Em resumo, estamos em melhor situação exportando computadores e importanto calçados do que estaríamos se quiséssemos proteger nossa indústria nacional de calçados em detrimento de nossas exportaçoes de computadores. É um argumento plausível e que poderia ter uma considerável legitimidade se os EUA possuíssem uma balança comercial favorável e baixo nível de desemprego. Sob as atuais circunstâncias, no entanto, é difícil conseguir essa legitimidade.

\section{UMA COALIZÃO NACIONALISTA NO CENTRO?}

Newfarmer e Mueller calcularam que 25 empresas controlam mais da metade do investimento industrial americano na América Latina. ${ }^{40}$ Essas empresas beneficiam-se de um número de leis fiscais favoráveis, recebem certos serviços especiais, tais como seguros (Corporação dos Investimentos Privados no Estrangeiro - Opic) e esperam o apoio geral do aparato governamental dos EUA. Enquanto a percepção de Hickenlooper, da conexão direta entre seus interesses e o interesse dos EUA predominar, essas 25 empresas poderão confortavelmente esperar o apoio completo do Estado. ${ }^{41}$ 
A visão de Hickenlooper do investimento estrangeiro pressupõe não apenas que os interesses das multinacionais são sinônimos dos interesses dos EUA, mas também que os inimigos das multinacionais são inimigos do capitalismo e, portanto, no "estilo de vida americano". Dai, quando as multinacionais se envolvem em disputas ou conflitos com um governo veementemente anticomunista, como o do Brasil, é difícil invocar fervor ideológico. O que é ainda mais sério, tornase difícil invocar apoio baseado nos interesses, mesmo de outros proprietários de capital. Os investidores no estrangeiro carecem mesmo do suporte político com o qual os produtores de armamento podem contar. Estes beneficiam-se do apoio dos trabalhadores, ansiosos por preservarem seus empregos, e do apoio dos Governos locais, ansiosos por preservarem sua fonte de impostos. As indústrias no exterior não têm nenhum desses apoios.

Por que razão proprietários de pequenas empresas - fábricas de calçados, por exemplo - não se agrupariam em torno de um programa nacionalista que envolveria o protecionismo das indústrias nacionais, $o$ fim das taxas e outros privilégios para investimento no estrangeiro e talvez, em caso extremo, o fim do apoio militar dos EUA aos regimes autoritários cuja política repressiva ao trabalho torna possivel as exportações? Se estivéssemos buscando um elemento nacionalista entre os pequenos capitalistas, a indústria de calçados seria o lugar mais óbvio para se procurar. ${ }^{42}$ Esta indústria é caracterizada pelo grande número de pequenas empresas e foi direta e severamente prejudicada pelas importaçð̃es. Mesmo as maiores empresas dessa indústria não foram capazes de obter sucesso em investimentos diretos no estrangeiro. Apesar de tudo isso, o nacionalismo da indústria de calçados não foi além de medidas especificas e particulares de protecionismo.

Poder-se-ia esperar que os mais aflitos dentre os proprietários das indústrias de calçados fossem os afastados do negócio. Na realidade, muitos tiveram alterações em suas carreiras que não podem ser consideradas desastrosas. Alguns conseguiram vender suas empresas por grandes somas e gozam hoje de uma aposentadoria confortável. Os mais jovens e de espirito mais empreendedor possivelmente se transformaram em importadores. Alguns foram mantidos pelas firmas que compraram suas empresas. (Um deles foi desenhar sapatos na Itália.) Talvez tenha havido desastres pessoais, mas isso parece não ter sido suficiente para gerar um impacto político.

$E$ aqueles que permaneceram na indústria, confrontando-se com uma maciça importação de calçados? Primeiro, as grandes empresas têm de ser excluídas de qualquer coalizão nacionalista. As quatro maiores companhias de calçados tiveram níveis maiores de lucro no período de 1970-73 do que entre 1963$66 .{ }^{43}$ Muitas delas envolveram-se pesadamente nas vendas a verejo e foram capazes de combinar produção própria com importação. Umas poucas fizeram investimentos diretamente no exterior. Em 1977, quando era intenso o lobby para se impor restriçōes à importação de calçados de Formosa e da Coréia do Sul, a U.S. Shoe Corporation, uma das maiores em- presas do ramo, "começou silenciosamente suas operaçōes no Extremo Oriente, em Taipei, Formosa".+4 Outras empresas descobriram que tentar obter o controle administrativo de firmas estrangeiras dá mais trabalho do que lucro e que podem obter lucros de fábricas estrangeiras, sem serem seus proprietários.

Entre as pequenas indústrias, aquelas que se especializaram no volume - ou seja, aquelas que produzem grandes quantidades de calçados baratos - foram as mais atingidas. Muitos admitem que empresas com essa especialização ou terão de mudar de linha ou irão à falência. Há outros tipos de indústrias de calçados, entretanto, em que as empresas locais têm mais vantagens. Em certos estilos, tais como botas pesadas e sapatos esportivos de couro, o estilo americano predomina. Em calçados de couro de alto preço, a mão-deobra direta representa somente $15-20 \%$ do valor do produto. Quando o fabricante estrangeiro paga o frete, os impostos, a estocagem é difícil para ele obter alguma vantagem no custo, mesmo que a mão-de-obra tenha sido muito barata. Nos segmentos de mercado de alto preço, onde a moda predomina, há uma grande vantagem em se estar próximo do mercado consumidor. Uma pequena empresa local pode atender ao varejista dentro de 25-35 dias, enquanto uma companhia brasileira ou chinesa necessita 6 meses.

Em resumo, há um número de áreas nas quais a pequena indústria local tem chance de sobreviver - pelo menos uma chance não inferiơ à normal para uma pequena empresa. Ela pode fracassar, como qualquer pequena empresa pode fracassar, mas não se verá privada, pela nova ordem econômica internacional, de uma oportunidade de competir. Além do que, mesmo aqueles que se vêem engajados em uma batalha pela sobrevivência em que os maiores oponentes são estrangeiros carecem de uma estrutura ideológica que possa leválos a uma política nacionalista.

Um empresário cuja companhia tinḩa sido forçada pela competição estrangeira a alterar de modo drástico (embora com sucesso) sua linha de produção era completamente antagônica aos esforços no sentido de se proteger a indústria de calçado. Ele sentia que as companhias americanas não poderiam competir com o Oriente em volume e que "não valia a pena tentar". Tarifas, quotas e subsídios "tornam os calçados mais caros para o consumidor comum, aumentam os impostos e aumentando, conseqüentemente, a inflação tornam mais caro para alguém na Alemanha a compra de um computador IBM". O surpreendente acerca de sua análise é que reflete com exatidão a posição internacionalista que se pode esperar de um diretor de uma multinacional. A descoberta de tal arquétipo internacionalista na pessoa de um pequeno empresário orientado para a produção local dá alguma indicação da hegemonia ideológica geral da posição internacionalista.

Mesmo os produtores de calçados que são inflexíveis quanto à necessidade de proteção normalmente não póem suas reivindicaçoes no contexto de nenhum programa político geral. Para aqueles que mantêm uma linha de produção de alto preço, "o declínio da habilidade artesanal americana" é o maior culpado. Os trabalhadores americanos não podem mais, por alguma 
razão, igualar a finura do artesão italiano. Trabalhadores esforçados e qualificados são cada vez mais difíceis de se encontrar. Vendo a fonte de seus problemas na falta de qualificação e motivação dos seus trabalhadores, eles são afastados de qualquer análise que possa colocá-los em oposição às multinacionais.

A competição na produção de grande volume tem mais possibilidade de levar a uma análise nacionalista. Um empresário que tinha observado a competição estrangeira transformar a posição de uma companhia de lucros de 500 mil dólares em 1969 para prejuízos de 100 mil dólares em 1976 e 1977 disse claramente: "Enquanto o Departamento de Estado apoiar ativamente governos que acreditam na supressão de seus povos, os empresários americanos não serão capazes de competir' '. Mesmo neste caso, entretanto, o resultado foi estoicismo, em vez de ativismo político.

Os fabricantes de calçados vêem o mundo em termos individualistas. Eles têm pouca fé na eficácia da política ou de açōes coletivas em geral. O pequeno empresário, mesmo quando ameaçado por mudanças estruturais que para um observador externo pareçam exigir uma ação política, vê soluções em termos de aumento da iniciativa individual ou se resigna. Testemunhar em comitês de congresso, trabalhar por intermédio da associação de indústrias, não é visto como um caminho eficaz. Nem há evidência de que esses pequenos empresários vejam sua situação em termos de luta contra as multinacionais. Eles têm consciência de que grandes empresas industriais podem tirar vantagem das importaçōes e não se interessam por protecionismo, mas a idéia de uma separação fundamental entre o capital voltado para a produção interna e o capital internacional não existe em sua visão do mundo.

Um rápido exame do setor da indústria de calçados sugere que a idéia de uma coalizão nacionalista montada pela pequena indústria orientada para a produção nacional e objetivamente atingida pela evolução da economia internacional é fantasiosa. A procura de conseqüências políticas das mudanças econômicas ligadas à "nova ordem econômica internacional" deve centralizar-se em algum outro ponto que não o capital nacional. Mas isto não quer dizer que o desaparecimento de centenas de indústrias de calçados e outras mudanças similares não tenham produzido qualquer efeito político.

Alguns desses efeitos podem ser vistos nos debates do Congresso. Em vários dispositivos recentes da legislação, que deveriam ser totalmente não-controversos, os internacionalistas descobriram uma oposição surpreendentemente forte. Medidas rotineiras, tais como a aprovação de fundos para o FMI ou um tratado de taxação com o Reino Unido, levaram a problemas inesperados. Talvez a mais violenta luta tenha sido a que objetivou a renovação da Corporação dos Investimentos Privados no Estrangeiro - Opic. No Congresso, o projeto da Opic foi posto de início no "calendário suspenso", que é reservado para a legislação não-controversa. Após dois dias de debate, a decisão tornara-se tão problemática que seus patrocinadores retiraram o projeto ao invés de levá-lo à votação final. $O$ debate deste projeto fornece uma boa indicação da erosão da posição internacionalista. Houve três principais pontos de ataque: primeiro, que os investimentos patrocinados pela Opic podem estar ligados ao fechamento de fábricas e à perda de empregos nos EUA; segundo, que a Opic beneficiava somente as grandes empresas, nada fazendo pelas pequenas; e terceiro, que os investimentos patrocinados pela Opic não levavam a objetivos desenvolvimentistas por serem muitas vezes frivolos, por se dirigirem geralmente aos maiores e mais avançados países do Terceiro Mundo (com freqüência aqueles com problemas de desrespeito aos direitos humanos) e por beneficiarem apenas as elites desses países.

O Deputado Leo Ryan, da Califórnia, liderou a disputa, argumentando que "o que nós realmente temos aqui é assistência a países altamente desenvolvidos, dando-lhes mais auxílio do que eles necessitam, para tomar os empregos de nosso próprio povo" .45 Outros seguiram sua linha, perguntando: "Não é também verdade que muitos dos produtos que inundam o mercado americano e tiram do povo sua oportunidade de emprego - peças de TV, aço, artigos de couro, vestimentas - são produzidos em fábricas estrangeiras, seguradas por este programa?"46 Alguns estavam mais perplexos do que agressivos, como o Deputado Danielson, de Los Angeles, que disse: "Perdi três fábricas de pneus (...) o pessoal da Business Round Table disse-me que me daria uma resposta. Até hoje, não a recebi. Talvez o meu amigo, aquele senhor da Califórnia [Mr. Ryan], tenha apontado o problema certo. Talvez estas atividades estejam sendo exportadas' ,7 $^{4}$

$\mathrm{O}$ apelo às pequenas empresas também forneceu um elemento útil para os oponentes do projeto. $O$ Deputado Long, de Maryland, introduziu uma emenda segundo a qual teria sido necessário que a Opic fornecesse "pelo menos $50 \%$ de todas as suas garantias às pequenas empresas (como definido pela Small Business Administration)"'.48 Quando o patrocinador do projeto argumentou que a emenda "tornaria o programa completamente inoperante", a resposta de Long foi imediata e óbvia: "Penso que o cavalheiro acabou de fazer a mais condenatória acusação ao programa da Opic que até hoje ouvi. O cavalheiro diz que não há lugar nos negócios ou mercados estrangeiros para pequenas empresas. O que poderia ser pior que isso?" "49

Os aspectos de "ajuda" da Opic também foram atacados. Ryan e outros apontaram que investimentos como cadeias de lanchonetes no Brasil, hotéis ITT Shuaton na Índia, alojamentos para safari no Quênia e serviços de aluguel de carros Avis na Malásia'"(...) não era o que nós pensávamos quando criamos a Opic para ajudar os paises pobres". ${ }^{50}$ Defensores dos direitos humanos mostraram que "(...) o que vemos a Opic fazer é dar mais e mais dinheiro(...) para companhias que investem em países onde há sérias e brutais violações dos direitos humanos" .51 O Deputado Long, de Maryland, rematou: "Este tipo de indústria que nós estávamos garantindo vai, por certo, beneficiar algumas pessoas. Vai beneficiar a classe dirigente".

Os defensores do projeto da Opic ganharam no fim. Mas o debate indicou a fragilidade da tradicional coalizão liberal-internacionalista que viu Jacob Javits e 
Hubert Humphrey se juntarem na defesa da Opic. Quando os defensores do projeto argumentaram que os investimentos americanos por ele fermentados aumentariam as exportações e o nível de emprego dos EUA, não convenceram tanto os seus colegas como o fizeram há cinco anos atrás. A concentração dos seguros da Opic sobre algumas das 500 empresas da Fortune tornou o fato mais irritante. ${ }^{52} \mathrm{O}$ ceticismo sobre os efeitos desenvolvimentistas do investimento direto era aparente durante todo o tempo. Se não fosse pelo esforço concentrado no lobby por um grande número de representantes da Opic e pelo fato de ela não estar exigindo fundo, o resultado teria sido diferente.

O debate não deu origem a uma coalizão nacionalista. Mostrou, sim, que os representantes de distritos liberais, da classe média (Ryan), comerciantes (Long), defensores de direitos humanos (Harkin, de lowa), representantes de distritos com fábricas fechadas (Danielson) e mesmo representantes de distritos rurais conservadores (Evans, da Geórgia) poderiam achar um campo comum na sua oposição quanto ao apoio estatal às atividades das multinacionais. ${ }^{53} \mathrm{~A}$ veemência da oposição à Opic foi mais surpreendente devido à espontaneidade de sua emergência. Ryan principiou a discussão quase por acaso, não por haver algum interesse de seus eleitores contra a Opic. Muitos deles provaveimente nunca ouviram falar dela. Os argumentos anti-Opic atingiram correntes ideológicas simpatizantes. Relatou-se que um Senador afirmou: "Como posso eu apoiar a Opic, quando os fazendeiros de meu distrito não conseguem empréstimos?"' A emenda de Long a favor da pequena empresa ganhou suporte não porque o pequeno capital orientado para a produção nacional estivesse pressionando, mas sim porque, segundo palavras de um observador com longa experiência no Capitólio, "o Congresso (especialmente a Câmara) reage visceralmente a qualquer assunto que envolva a pequena empresa".

O trabalhador envolveu-se na batalha sobre a Opic apenas depois de Ryan tê-la transformado numa luta. $O$ fato de o trabalhador ter-se envolvido representa parte de um despertar gradual da tradicional instância internacionalista da AFL-CIO. Esta federação tem sempre achado mais fácil entender-se com os defensores da posição internacionalista, como Jacob Javits, do que com representantes da pequena empresa, cujos poderes e lucros são mais diretamente ameaçados pelo sindicato. Mas como o fechamento de fábricas expandiu-se na proporção da expansão do investimento direto no estrangeiro, os argumentos dos internacionalistas começaram a debilitar-se.

Mesmo que o pequeno capital orientado para a produção nacional fosse congenitamente incapaz de montar uma ação política coletiva, sua desventura teria efeito político. A pequena empresa, em abstrato, tem um carisma político semelhante àquele da burguesia nacional em países como o Brasil. Cria-se uma potente combinação ideológica quando a desventura da pequena empresa é conectada com a perda de empregos.

lsto não significa que as boas relações entre as multinacionais e o aparato estatal dos EUA hajam terminado ou estejam para terminar. O Departamento de
Comércio e outros setores do Executivo encarregados de atender às necessidades das multinacionais continuarão por certo a executar seu trabalho. Exercendo de modo ativo sua influência, as multinacionais podem, provavelmente, fazer passar qualquer legislação de que necessitem. O mais marcante a respeito do debate da Opic foi a própria ocorrência desse debate. Uma persuasão não-questionada é uma coisa, uma ideologia questionada é outra. $O$ fato de a ideologia internacionalista ter sido questionada de forma tão violenta, numa época em que os círculos dirigentes estavam repletos de representantes do que é, certamente, a epitome da perspectiva internacionalista - a Comissão Trilateral - deve ser objeto de atenção para as multinacionais". ${ }^{44}$ Pior ainda, suas dificuldades politicas nos EUA repercutem politicamente em paises como o Brasil.

\section{REPERCUSSÕES NACIONALISTAS}

$O$ apogeu dos sentimentos pró-EUA, entre aqueles que controlam os aparatos estatais brasileiros, ocorreu há 10 anos atrás quando Castelo Branco era presidente e Roberto Campos responsável pelo Ministério da Fazenda. Naquele tempo, os EUA atraiam como baluarte do anticomunismo. O apoio americano tinha sido crítico para assegurar a fácil ascensão dos militares ao poder. A ajuda, o comércio e o investimento americanos constituíram o principal suporte para o modelo de desenvolvimento que os militares estavam tentando instalar.

No fim da década de 70, a mudança de caráter da economia internacional fez com que a confiabilidade em relação aos EUA parecesse menos atraente. Após testemunhar o déficit crônico de sua balança comercial com os EUA por mais de 30 anos, o Brasil vê-se hoje tratado como um competidor perigoso, suspeito de culpa no tocante a práticas ilicitas de comércio. Esses temores parecem mais justos se dirigidos contra o Japão e a Alemanha. Aos brasileiros podem apenas parecer injustos e hostis. Apesar de tudo, o Brasil não só tem uma balança comercial negativa, como ainda é uma fonte menor de exportações de manufaturados para os EUA. Um observador brasileiro, acompanhando os debates da Opic, poderia ficar desconcertado ao ver o Brasil ser constantemente usado como exemplo de um desses "paises altamente desenvolvidos" que estão "obtendo mais auxilio do que necessitam, para tirar empregos de nosso próprio povo".

Em defesa da Opic, o Deputado Bingham de Nova York reconheceu que "demasiadas atividades da Opic estão centralizadas em países como o Brasil"' e mostrou que "outro dia ainda, por exemplo, a Opic anunciou que não haveria mais garantia geral para os seguros feitos no Brasil e em outros países onde a renda per capita fosse superior a 1.000 dólares" $55^{10}$ Deputado Long atacou a Opic com veemência por ter auxiliado a indústria siderúrgica no Brasil:

“Em 1977, a Opic financiou um projeto siderúrgico no Brasil, um pais que já recebeu mais de 940 milhões de dólares como financiamento estrangeiro para sua indústria siderúrgica (...) eu visitei uma de suas usinas. Elas são lamentáveis. Estão obtendo subsídios de seu 
próprio Governo, além de receberem do nosso. Mas, desde que o país tenha siderúrgicas, irá produzir aço e exportá-lo, não importa quão antieconômica seja a produção, e deixará de comprar dos EUA. A indústria siderúrgica brasileira aumentou suas exportações de aço para os EUA mais de 160 vezes entre 1959 e 1974 '.56

Tal retórica não perturbaria se parasse por aí. Mas, quando ela é acompanhada de ações concretas, tais como a imposição de taxas alfandegárias de compensação sobre tesouras e fios têxteis e pressões para a remoção de incentivos à exportação na indústria de calçados, isto se torna uma indicação de confronto potencialmente sério entre o capital, voltado para a produção interna nos EUA e uma característica central da expansão da exportação brasileira. A questão tornarse-á particularmente importante no fim da década de 70, quando os privilégios para a exportação da América Latina aos EUA terão de ser renegociados.

Ao mesmo tempo em que o atrito econômico com os EUA aumenta, o anticomunismo militante (pelo menos no plano internacional) parece estar perdendo seu sentido econômico. Como indica o quadro 1, quando o problema é solucionar os desequilíbrios comerciais, os países socialistas aparecem como parte da solução e os EUA como parte do problema. Não apenas a União Soviética e a Europa Oriental oferecem bons mercados às exportações brasileiras, mas as antigas colônicas portuguesas na África, hoje socialistas, são também áreas de potencial econômico promissor. No plano Interno, o anticomunismo permanece necessário para a manutenção dos privilégios de classe; internacionalmente, todavia, não tem mais sentido uma interpretação rígida do que é ser membro do "mundo livre".

Para as multinacionais americanas que operam no Brasil, as vantagens políticas da "cidadania" americana tornaram-se muito mais ambíguas do que o eram há 10 anos. No caso da Westinghouse, por exemplo, a cidadania americana foi um obstáculo intransponivel para a obtenção de um contrato de reatores nucleares no valor de muitos bilhões de dólares, embora pudesse ter sido o candidato mais bem colocado. Nenhuma outra companhia sentiu-se tão diretamente atingida, mas há um desagradável sentimento de que, como o diretor de uma multinacional disse, o atual estado das relações Brasil-EUA apresenta uma qualidade negativa para as multinacionais americanas que tentam operar no Brasil.

A afirmação do Business Latin America de que "o comércio e investimento americanos na região poderiam ser postos de lado, em favor de investidores europeus e japoneses", deve ser tomada como uma paranóia ou como uma tentativa de forçar as decisões da política americana para uma instância mais claramente internacionalista. $O$ fato é que o protecionismo, em combinação com a política de Carter quanto a direitos humanos e a não-proliferação, é um embaraço às multinacionais e acentua a possibilidade de uma política nacionalista por parte do Estado brasileiro.

Seria muito rudimentar sugerir que o Estado brasileiro, em um simples quid pro quo, reagisse contra as multinacionais que pretendem operar em seu ter- ritório. Em primeiro lugar, o Brasil ainda está engajado em um modelo desenvolvimentista, baseado na tríplice aliança e, por essa razão, deve ter o apoio das multinacionais para executar o projeto de acumulação escolhido. Qualquer discriminação aberta contra as multinacionais de algum país central - especialmente contra as americanas que, apesar de tudo, representam quase três vezes mais investimento que as do Japão e Alemanha - limitaria a flexibilidade de barganha do Estado e ameaçaria o sucesso geral da tríplice aliança.

As diretrizes a respeito da regulamentação, restrição e controle das multinacionais são decididas e têm por base as necessidades imediatas e não as reações ideológicas ou emocionais aos debates do Congresso americano. Se a GM é levada a concordar com o programa de exportações é porque o Brasil tem de achar uma solução para seus problemas de balanço de pagamentos e não porque personalidades governamentais brasileiras se irritavam em virtude de acusações de tortura. Se a IBM não é autorizada a instalar uma subsidiária com capital próprio é porque a Marinha brasileira pode ter capital investido na Digibrás ou porque investidores locais, com conexões políticas, vêem uma possibilidade de participação lucrativa na indústria de computadores se a IBM for excluída, e não porque a Associação Americana dos Produtores de Fios conseguiu impor taxas alfandegárias de compensação sobre os fios têxteis brasileiros.

A conexão entre os debates sobre políticas internacionalistas nos EUA e a possibilidade de pressões nacionalistas crescentes sobre as multinacionais americanas é mais sutil e indireta. A existência de políticas americanas que não são favoráveis às aspirações do Brasil (quer quanto à necessidade de expansão das exportaçôes, quer quanto ao grau de repressão que o modelo requer) legitima respostas equivalentes por parte do Brasil. Privar a GE de seus direitos a uma parcela das encomendas nacionais de locomotivas parece mais legítimo numa ocasião em que congressistas americanos aplaudem a decisão da Opic de não garantir novos investimentos no Brasil. Os interesses da Equipamentos Villares podem ser a causa mais próxima, mas o surgimento do nacionalismo defensivo nos EUA contribui para a legitimidade da opção nacionalista no Brasil.

Para a escolha de diretrizes racionais no Brasil, a resposta aos ecos do nacionalismo americano deve envolver algo mais que questões de legitimidade. Assim como as multinacionais devem assessorar a estabilidade de governos do Terceiro Mundo (leia-se continuidade de regimes favoráveis ao capital internacional), assim também os países como o Brasil devem considerar a sério a possibilidade de que o comportamento futuro das multinacionais americanas depende em parte do clima político dos EUA. Em 1977, a Westinghouse foi impedida de fornecer um reator nuclear ao Brasil. Estaria além das possibilidades reais considerar que em 1984 o Congresso pudesse impedir a IBM de facilitar o acesso dos brasileiros à sua tecnologia de computadores? Se tal possibilidade existe a decisão de excluir a IBM torna-se mais racional.

O nacionalismo americano fortalece o nacionalismo brasileiro, e este, se restrito a uma prudente barganha, 
reforça o envolvimento das multinacionais na tríplice aliança. Como reagirá a Westinghouse quando observar a GE perder uma grande venda de locomotivas? Como reagirão a GE e a Westinghouse quando virem a IBM sendo excluida da indústria brasileira de computadores? O Brasil não é somente um mercado que está crescendo mais rapidamente que os mercados de muitos paises desenvolvidos, mas é também uma economia em que a taxas de lucro apresentam-se excepcionalmente altas. Se for necessário alterar a política de busca de recursos, de forma a agradar os brasileiros, por que não? Se isso significa que uma determinada multinacional produzirá um pouco mais no Brasil, importará um pouco menos dos EUA, e exportará um pouco mais de volta aos EUA, por que não? O Governo brasileiro observa o balanço de pagamentos de cada multinacional individualmente; o mesmo não ocorre com os Estados Unidos. A recusa em cooperar com o Governo brasileiro poderia resultar numa perda dos incentivos do CDI; os EUA não têm nem mesmo uma definição precisa de quais são as conseqüências da cooperação.

\section{ECONOMIA TRANSNACIONAL E POLÍTICA NACIONAL}

Os temas deste trabalho abrangeram desde as relaçסes comerciais do Brasil com a Bolívia, passando pela opinião política dos fabricantes de calçados da Nova Inglaterra, até os ataques do congresso aos abrigos para Safari no Quênia - sempre na tentativa de esclarecer a natureza das relaçðes Brasil-EUA na década de 70 . A lógica subjacente a esta combinação de evidências disparatadas e um tanto incomensuráveis deve ser acentuada.

O ponto de partida é a transformação econômica em certas áreas da periferia. Nada, da análise que foi apresentada, poderia ser estendido ao Afganistão, à Nigéria, a Zâmbia ou ao Paráguai. Somente alguns países passaram pelo tipo de desenvolvimento dependente associado à capacidade industrial local e à formação de uma tríplice aliança entre capital estatal, nacional e multinacional. Nesses países as multinacionais podem ser subordinadas a projetos de acumulação nacional, mas somente na presença de uma pressão nacionalista constante. Nacionalismo constante, no sentido em que o termo é utilizado aqui, é uma caracteristica estrutural da tríplice aliança.

A expansão da exportação de manufaturados para os países principais é vital para o modelo de crescimento econômico que surgiu sob a égide da tríplice aliança - vital por causa da necessidade econômica de resolver desequílibrios externos criados pela industrialização baseada na importação intensiva, e ainda porque a expansão das exportaçð̃es é um modo de resolver tais desequílibrios de uma forma que é ao mesmo tempo atraente para as multinacionais e que não se mostra ameaçadora ao capital nacional.

Neste ponto aparece uma divisão entre os interesses das multinacionais e os do capital americano, cuja primeira preocupação é a expansão da economia dos EUA. Independentemente da questão de exportar para os EUA, sérias interrogações podem ser levantadas quanto ao fato de a acumulação levada a efeito pelas multinacionais na semiperiferia estar-se fazendo às custas da acumulação em seus paises de origem. As evidências existentes sugerem que pelo menos a mãode-obra dos EUA está sendo prejudicada. Na medida em que pequenos empresários encontram-se cada vez mais ameaçados pelo influxo de manufaturados estrangeiros, as contradições entre as preferências das multinacionais e os interesses nacionais tornam-se mais agudas.

Nessas condições, programas como a Opic põem a prova os limites da "crença ingênua e incontestável" de que o apoio às empresas deve basear-se no interesse nacional, uma vez que essas empresas pertencem a cidadãos americanos. A Opic representa um subsidio público disponivel apenas para as companhias empenhadas em ampliar a capacidade econômica de outros países que não os EUA, e utilizado, na prática, por pequeno número das maiores multinacionais. Numa época em que fábricas estão sendo fechadas por causa da concorrência estrangeira, o desemprego é um problema e os déficits do balanço de pagamentos são crônicos, convencer os políticos de que tais subsidios atendem ao interesse nacional requer certa habilidade. $A$ análise da oposição a programas como os da Opic propicia uma mensuração da reação política, nos EUA, à crescente tendência das multinacionais de deslocar a produção para fora do país.

$O$ resultado que se propõe e o crescente afastamento das multinacionais em relação ao aparato político de seus países de origem. Este aspecto deve ser menciona: do com muito cuidado. Não se está afirmando aqui que a classe capitalista nos Estados Unidos esteja dividida em segmentos internacionalistas e nacionalistas em luta pelo controle do governo dos EUA. O pequeno capital orientado para a produção interna tem todas as fraquezas políticas que são tradicionalmente atribuidas à pequena burguesia pelos marxistas. Considerando que alguns pequenos empresários continuam a encontrar áreas lucrativas mesmo nas indústrias nacionais afetadas de modo mais severo, percebese que há consciência em relação a um prejuízo de âmbito coletivo. Mesmo os pequenos empresários, orientados para a produção interna, estão imbuídos da ideologia internacionalista do livre comércio.

$O$ presente afastamento das multinacionais em relação à política dos seus países de origem parece ter ocorrido sem nenhuma campanha geral significativa da parte do pequeno capital orientado para a produção interna, e também com apenas uma pequena pressão das associações trabalhistas. O grau de desgaste da posição ideologicamente hegemônica da instância internacionalista é impressionante, precisamente porque ocorreu de forma antecipada em relação a pressões de grupos cujos interesses seriam afetados, e não como resultado dessas possíveis pressóes. $O$ Governo continuará, com certeza, a agir de acordo com os interesses do capital internacional. Mesmo no Congresso, a posição internacionalista será vitoriosa na maioria das vezes. A questão não é que o Governo dos EUA tenha-se tornado nacionalista, mas, antes, que a frente internacionalista esteja começando a apresentar algumas falhas. 
A tentativa de manifestação de sentimentos nacionálistas nos EUA tem o efeito de aumentar as pressões nacionalistas no Brasil, não só porque as ações dos EUA justificam mais o nacionalismo brasileiro, como porque elas estimulam politicas defensivas em atencipação. A resposta das multinacionais será procurar uma acomodação com as demendas brasileiras e, desta forma, aumentar as distâncias entre elas e os interesses internos dos EUA. Desde que prevaleçam certas condições anteriores, a aproximação que já foi alcançada entre as multinacionais e o Estado brasileiro se autosustentará.

As condições anteriores são importantes. Acreditase que as taxas de lucro e de crescimento continuarão a ser superiores no Brasil. Se o protecionismo nos países desenvolvidos ou alguma outra alteração na economia internacional levar a uma estagnação real e a taxas de lucro mais baixas no Brasil, então toda a dinâmica se transformará. A classe trabalhadora brasileira poderia também interferir no processo. Uma expansão, ou mesmo a repetição crônica de uma onda de greves, tal como ocorreu em São Paulo em 1978, alteraria o cenário de modo substancial. Se a repressão efetiva das demendas da classe trabalhadora falhasse, nem o nível corrente de lucratividade, nem a presente definição restrita de nacionalismo poderiam ser garantidos; e a capacidade de atração do Brasil em relação às multinacionais seria questionada.

As conjeturas sobre a evolução do ambiente norteamericano mostram-se mais conservadoras. Aceita-se o fato de que continuarão os problemas atuais como a balança comercial e com a manutenção dos empregos em indústrias básicas e que, portanto, as relaçōes com a economia internacional permanecerão problemáticas. Além disso, entende-se que as tentativas de se enfrentar os ajustamentos estruturais na economia dos EUA continuarão nos rudimentares níveis do presente.

As suposições acerca do futuro do ambiente norteamericano são conservadoras, principalmente porque não incluem previsões de uma militância crescente por parte dos trabalhadores. Desde 1960, os trabalhadores dos EUA têm recebido menos compensação por hora de trabalho do que qualquer outra classe trabalhadora no mundo desenvolvido. Por quanto tempo isto pode continuar sem estimular uma maior militância dos trabalhadores ou uma mudança em direção a políticas socialistas mais explicitas é impossível dizer. Se um desses fatos ocorresse, o processo de afastamento das multinacionais em relação a seu país de origem poderia acelerar-se.

As implicações desse argumento permanecem radicais, não importando o modo pelo qual se tente definilas ou avaliá-las. "O que é bom para a General Motors é bom para os Estados Unidos" tem sido uma premissa básica duradoura do pacto de dominação existente nos EUA. Tais premissas ideológicas têm sido mais difíceis de se impor na América Latina, porque um amplo segmento do capital é estrangeiro. $O$ resultado disso foi a instabilidade da dominação burguesa, mas a hegemonia internacional dos Estados Unidos compensou a instabilidade nacional. Uma vez que nacionalismo pode ser definido, mesmo nos EUA, de maneira diferente em relação aos interesses do setor mais importante do capital, a caixa de Pandora está aberta.

Quando o Deputado Long questiona se os valiosos serviços que a Opic presta às multinacionais são do interesse nacional, ele está questionando uma premissa ideológica fundamental. O que Veblen tinha em mente ao falar da "crença ingênua e incontestável" consistia em tomar uma classe por outra. No seu desejo de tirar vantagens de oportunidades lucrativas em países semiperiféricos como o Brasil, o capital internacional pode terminar por expor seu aspecto ideológico mais seriamente do que poderia admitir.

1 Business Latin America, p. 57, 1978.
2 Ibid., p. 59.

3 Ibid., p. 131.

4 O termo nacionalismo é usado às vezes, especialmente na América Latina, para se referir às diretrizes ou posiçōes ideológicas que respondem aos interesses de uma nação como um todo, ou seja, aos interesses de toda a população. Em uma sociedade de classes tal definição é bastante problemática, e por esta razão uma definição mais restrita à perspectiva da classe dominante será usada aqui: políticas nacionalistas são aquelas que objetivam maximizar a taxa de acumulação de capital dentro dos limites de um dado país. $O$ termo nacionalista não tem implicaçð̃es diretas de bem-estar social ou de distribuição de renda. Definido nacionalismo desta maneira restrita, um regime pode ser nacionalista e ao mesmo tempo repressivo e com distribuição desigual dos privilégios. As políticas nacionalistas podem ser consideradas do interesse de toda a população na medida em que os cidadãos locais possam ser capazes de exercer pressões políticas sobre a distribuição dos benefícios da acumulação que ocorre dentro do mesmo "conjunto de normas governamentais". A palavra internacionalismo será usada com as mesmas restriçōes capitalistas do nacionalismo - referindo-se às politicas ou ideologias que tentam maximizar a acumulação do capital, sem considerar a localidade geográfica dessa acumulação. Para uma discussão análoga, mas ligeiramente diferente, acerca do nacionalismo e do internacionalismo, veja Schurmann, Franz. The logic of world power: an inquiry into the origins, currents, and contradictions of world politics. New York, 1974.

5 Cardoso, Fernando Henrique. As Tradições de desenvolvimento associado. Estudo CEBRAP, 8:41-75, 1974.

6 Wallerstein, Immanuel. The Rise and future demise of the world capitalist system: concepts for comparative analysis, Comparative Studies in Society and History, 15(4):387-415, Sept. 1974. Veja também Wallerstein, Immanuel. Semi-peripherical countries and the contemporary world crisis. Theory and Society, 3(4):461-84.

7 Evans, Peter B. Multinacionals, state-owned corporations and the transformation of imperialism: a Brazilian case study. Economic Development and Cultural Change, 26(1):43-64; Dependent development: the alliance of multinational state-owned and local Capital in Brazil. Princeton, New Jersey, a ser publicado brevemente.

8 Sunkel, Oswaldo. Transnational integration and national disintegration in Latin America". Social and Economic Studies, 22(17):132-76.

9 Cardoso, F. H \& Faletto, Enzo. Dependência e desenvolvimento na América Latina: ensaio de interpretação sociológica. Rio de Janeiro, 1973.

10 Newfarmer, Richard \& Mueller, Willard. Multinational corporations in Brazil and Mexico: structural sources of economic and noneconomic power. Relatório ao Sub-comitê sobre Corporações Multi- 
nacionais, Comitê de Relaçð̃es Exteriores, Senado dos EUA, Washington D. C, 1975.

11 Cardoso, Fernando Henrique. op. cit. p. 60.

12 Veja, por exemplo, Connor, John M. \& Mueller, Willard. Market power and profitability of multinational corporations in Brazil and México. Relatório ao Subcomitê de Política Econômica Externa, Comitê de Relaçð̌es Exteriores, Senado dos EUA, Washington D. C., 1977.

13 Moran, Theodore. Multinational corporations and the politics of dependence: copper in Chile. Princeton, New Jersey, 1974.

14 Business Latin America, p. 193-307, 1977.

15 Ibid, p. 196-299, 1975.

16 Ibid, p. 159, 1978.

17 Comissão Econômica para a América Latina - ECLA. Economic survey of Latin America. New York, 1976. p. 233

18 Business Latin America, p. 185, 1976.

19 Comissão de Tarifas dos EUA. Implications of multinational firms for world trade and investment and for $U$. S. trade and labor. Relatório ao Comitê de Finanças, Senado dos EUA, Washington D.C., 1973.

20 O'Donnell, Guillermo. Reflections on the patterns of change in the bureaucratic-authoritarian state. Latin American Research Review 13(1):3-39. Veja também Serra, José. Three mistaken theses on the connection between authoritarianism and economic development. In: Collier, David, ed. The New authoritarianism in Latin America. Princeton, New Jersey, 1978.

21 Serra, José op. cit. quadro 7.

22 Business Latin America, p. 155, 1978.

23 Wall Street Journal, p. 20, Jan. 13, 1978.

24 Business Latin America, p. 75.

25 Departamento de Comércio dos EUA. Brazil, survey of U.S. export and import opportunities: chemical and petrochemical industries. Escritório de Comércio Internacional, Washington D. C. 1974.

26 Business International, p. 204, 1976.

27 Business International, I Nov./1st, 1976.

28 Muller, Ronald \& Moore, David. Brazilian bargaining success in Befiex export promotion program with the transnational automotive industry. New York, 1978.

29 Id ibid. quadro 2.

30 Business Latin America, p. 149, 1978.

31 Peter Evans, Foreign investment and industrial transformation. Journal of Development Economics, 3(4):119-39.

32 Embora o enfoque aqui seja sobre a pequena empresa, há também, obviamente, exemplos de grandes empresas orientadas para a produção interna ameaçadas pelas importaçð̃es. A análise de Steven Volk sobre a indústria siderúrgica fornece bom complemento da discussão aqui apresentada.

33 Martins, Luciano. Nação e cooperação multinacional. Rio de Ja- neiro, 1975, p.99 (Coleção Estudos Brasileiros, p. 4.)

${ }^{34}$ Subcomitê sobre Corporações Multinacionais, Comitê de Relaçðes Exteriores, Senado dos EUA. Hearing on multinational corporations in the dollar devaluation crisis and the impact of direct in vestment abroad in the U.S. economy, Part 13. Washington D.C. 1976 p. 116.

35 Id. ibid. p. 117

36 Musgrave, Peggy. Direct investment abroad and the multinationals: effects on the U.S. economy. Prep. para uso do Subcomitê sobre Corporações Multinacionais, Comitê de Relações Exteriores, Senado dos EUA, Washington D.C., 1975. p. XVI, XVII.

37 Veja, por exemplo: Stobaugh, Robert, et alii, U.S. Multinational enterprises and the U.S. economy. In: Bureau of International Commerce, U.S. Department of Commerce, The Multinational corporation. Washington D.C., 1972.

38 Subcomitê sobre Corporaçðes Multinacionais. Hearings. p. 107. 39 Id. ibid. p. 165.

40 Newfarmer, Richard \& Mueller, Willard. op. cit. p. 43.

41 Por percepção de Hickenlooper quero dizer a suposição de que os aparelhos de Estado dos EUA devem servir para apoiar os interesses das multinacionais em suas disputas com paises do Terceiro Mundo, como foi expresso na famosa emenda Hickenlooper.

42 As entrevistas com executivos da indústria de calçados, sobre as quais se baseia parcialmente a discussão sustentada no texto, representam apenas uma parcela muito pequena dos fabricantes da Nova Inglaterra. Por não terem sido selecionados de forma sistemática, não são necessariamente representativos. Nenhum deles, por exemplo, era ativo na Associação Americana das Indústrias de Calçados. No entanto, os resultados dessas entrevistas são bastante consistentes com os comentários de observadores externos com relação à falta de atividade política organizada da parte do pequeno capital voltado para a produção interna.

43 Associaçăo Americana das Indústrias de Calçados - AFIA. Footwear manual 1977. quadro 14.

44 The Wall Street Journal. p.2, Mar. 3, 1978.

45 Congressional Record, p. H12058, Oct. 2, 1977.

46 Ibid., Oct. 3, 1977.

47 Ibid., p. H1450, Feb. 23, 1978.

48 Ibid., p. H12112, Nov. 3, 1977.

49 Ibid.

50 Ibid., p. H12054.

51 Ibid., p. H12057.

52 Ibid., p. H1443, Feb. 23, 1978.

53 Ibid., p. H1454.

54 Frieden, Jeff. The Trilateral Commission: Economics and Politics in the 1970's. Monthly Review, 29(7):1-19.

s5 Congressional Record, p. H1441, Feb. 23, 1978; p. H12056, Nov. 2,1977 .

56 Id. ibid. p. H1451, Feb. 23, 1978. 